\title{
Human Capital and Production Structure: Evidence from Greece
}

\author{
Eleni Giouli \\ Director of the E-Learning Program of the \\ National and Kapodistrian University of Athens, \\ Yorgos Pisinas \\ Research Assistant, National and \\ Kapodistrian University of Athens, Greece \\ Anna-Maria Kanzola \\ Research Assistant, National and \\ Kapodistrian University of Athens \\ Panagiotis E. Petrakis \\ Professor, National and Kapodistrian \\ University of Athens, Greece, corresponding author
}

\begin{abstract}
The present paper offers a theoretical review of the concept of human capital and its component elements, namely Knowledge, Skills, Abilities and Working Activities, and attempts to sketch the requirements of the production structure in the Greek economy. In addition, the role is stressed of the educational model in Greece in positively affecting the changes underway under the simultaneous impact of the $4^{\text {th }}$ industrial revolution and COVID-19.
\end{abstract}

Keywords: human capital, 4th industrial revolution, production transformation, Greece

\section{Introduction}

Human capital as an essential component of economic growth has been extensively studied. As an element which founds human societies and (economic) continuity, knowledge expands the range of (economic) activities by reducing the time required through its intergenerational transmission, thus transforming economies and structures of production. In contemporary economies, the constant changes brought about by technological developments, create shifts in the needs of the productive model and, hence, in the labor demands of businesses. 
This paper attempts to establish the rudiments of the relation between human capital and productive model in the context of the Greek economy. Part 2 concerns an overview of the theoretical underpinnings of human capital. The theory of human capital bases economic development on both exogenous and endogenous models of development. Thus, in part 3, we focus on furthering the theory of human capital.

Out of a range of approaches, we focus on the most contemporary one which interrelates the requirements in human capital with the current tasks and activities of labor. The characteristics of human capital are analyzed through its internal categorization, whereby it consists of Knowledge, Skills, Abilities and Working Activities. This approach is not new (Autor, 2013; Acemoglu and Autor, 2011) but in the present paper, the effects are analyzed of the two great economic crises of 2008 and 2020 in the categorization of the quality of human capital and technological change (part 4). In part 5, concluding remarks are presented and possible recommendations for economic policy are discussed .

\section{The Theoretical Background of Human Capital Theory}

The emphasis on the concept of human capital as a growth factor makes its appearance in the 1950s. In general, the reference to human capital involves people's abilities and skills and the productive wealth that inheres in labor, knowledge and skills, thus contributing to the economic prosperity of individuals (OECD, 2001).

The importance of human capital and of education had already been noted in the era of the classical economists. Smith (Smith, 2007) acknowledged the acquisition of knowledge as a process that was expensive but beneficial for the wealth of nations. Owen (Bernard et al., 1988) recognized the fundamental importance of socialization as he believed that individuals' behavior and thinking could be modified by changes in the physical environment. Education was the essential means for improving quality of life, as was technology.

Even though the abstract concept of human capital and the view that education could affect scale economies both existed, the 1940s and 1950s with the neoclassic approach of the models of economic growth were the ones that consolidated the concept of human capital by using models to include and define the sense of human capital. In the 1940s, Solow and Swan (Dimand and Spencer, 2008) developed an exogenous model of growth. The Solow-Swan model states that long-term development is achieved through the accumulation of capital, specialized labor (human capital), population growth and technological progress (Solow, 1956).

Through Solow's exogenous model of growth, attention was increasingly paid to human capital (Miner, 1958; Shultz, 1961) leading in the 60s, to Becker's approach to human capital. In Becker's work (1994) human capital is conceived as an investment choice for individuals in the context of a cost benefit analysis. Following that, in the 1980s and 1990s, the endogenous models of growth appear (Lucas, 1988; Romer, 1991) in which education is incorporated and becomes the main factor of change 
within economies with particularly positive effects on human capital and economic growth.

Later, in the endogenous model of technological change of Galor and Weil (Galor and Weil, 2000) a solution is provided to the problem of the Malthusian Trap. Specifically, the accumulation of human capital leads to an increase in per capita income which, in turn, implies an increase of earnings in relation to human capital. This mechanism provides incentives for an even greater investment in human capital and knowledge, as well as a change of behavior on the part of parents who are now having fewer but better educated children. Thus, the change of demographic characteristics follows a shift from the extensive utilization of labor forces to an intensive one, through the operation of human capital (Galor and Weil, 200). This fact is attested to by the increase of children enrolled in primary education (Winthrop et al., 2018).

These processes led to an endogenous perspective of inclusion of human capital to economic theory coinciding with the movement of microfoundations of economic theory, mainly with the aim of improving its predictive capacity (Petrakis, 2020b). They also led to the theoretical research of growth in knowledge and innovation within the rational choice frame of action, but also to the need for an interdisciplinary approach that would encompass all the relevant determining factors (Petrakis, 2020a, 2020b).

In recent years, with environmental developments at center stage, the same is the case with the concept of sustainable development for the utilization of (nonrecyclable productive) factors (Arrow et al., 2004). In this process, human capital can play an important role (González-Salamanca et al., 2020; Maremveliotakis and Manioudis, forthcoming; Osiobe, 2019). The development of human capital in this process is critical (Goldin, 2016; World Bank, 2019) and it hinges, by and large, on the efficiency and culture of the prevalent institutions and on the extent to which nations exhibit resilience (Petrakis, 2020b).

The institutional framework pursues through structural changes the improvement of conditions within economies regarding growth as well as social cohesion. These measures concern the improvement of conditions through promoting education, improving productivity and work conditions and reducing discrimination in the workplace (Borjas, 2015; Ngai and Petrongolo, 2017). In general, the quality of a country's education and literacy levels are reflected in the qualitative characteristics of the human capital (Bloom et al., 1914) which creates economies of scale and efficient resource management (Romer, 1990). The effect of knowledge (qualitatively) on human capital (Nelson and Phelps, 1966) is seen in the ability to emulate successful techniques of the productive process which are employed in other developed economies. 


\section{Describing Human Capital}

The measurement of human capital may be done either through the budget allocations for education or through the (marginal) productivity of labor (Borjas, 2015). The evaluation of human capital and its (productive) potential will need to take into consideration the needs of the existing production structures as well as the historical development of the cultural background.

At the turn of last century, the production structure required mainly knowledge at the level of functional literacy (that is to say, writing, reading, arithmetic and comprehension) insofar as the level of the technology was congruent with these requirements. One way of evaluating human capital is to break it down into its component elements. The approach that emerged after Becker's work, recognized two types of labor competencies, a "general" one which applied to the great number of businesses and a "specific" form that concerned specific businesses.

In other words, it entailed a distinction between competencies at the level of general knowledge and specialization in the context of the needs of specific enterprises. In terms of such specialization, individuals derived (upon completing their education) the benefits of knowledge accumulation with higher returns. Practically, this means that the initial categorization had to do with a distinction between levels of education and concomitant (choices of) specialization which is broken down into the cost of the provision of education, although without specifying the kind of educational provisions. This is a cumulative approach to the value of human capital which can scarcely be reduced to partial qualitative components.

In an attempt to arrive at a more specialized analysis of the components of human capital and how it is accumulated, Shaw (Shaw, 1984) introduced the concept of "occupational investment" to explain the accumulation of human capital on the basis of which, investment in the know-how of professions with common (or closely allied) characteristics, leads to "transferrable skills" through the contiguous branches of those professions. Next, Neal (Neal, 1995) confirmed the existence of "transferrable skills" since the earnings of the unemployed who were incorporated in the labor market related to levels of their earnings in their old affiliations, prior to unemployment. With Neal's contribution (Neal, 1995), the theory of Becker was subjected to a critique which emphasized the concepts of "industry specific" and "occupation specific" human capital -which, however, is not lost as it was in Becker's firm-specific theory, but accumulates and is utilized in comparable jobs with similar needs.

Another concept, that of "task specific" human capital (Gibbons and Waldman, 2004) links the accumulation of human capital with the requirements of specific jobs. In essence, this approach establishes the idea that different kinds of work entail different requirements from (the qualitative kind of) human capital. 
As different industries have different requirements of human capital, it makes sense to distinguish between their production structures so as to analyze their work-related features. In terms of distinguishing between kinds of production structures, three basic industries are found: a) the primary sector of agricultural production and mining, b) the secondary sector of processing and industry and c) the tertiary sector of services. This distinction, however does not provide details -beyond broad logical inductions- about the skills and knowledge that are required.

For the purpose of evaluating the skills and knowledge required in each industry data bases of occupational posts are used, comprised by statistical services and international organizations. In these data bases, the different occupations are classified and grouped into clusters of related professions. The three such largest data bases are $0^{*}$ NET of the US statistical services and ministry of labor, ESCO which is put together by the European Commission and CEDEFOP.

O*NET has 1016 occupations classified under 23 large clusters, 98 small groups and 459 broader occupations. ESCO is a data base of 2942 occupations classified on the basis of ISCO-08, into 10 large clusters before being further subdivided into various subcategories. The catalogues note the requirements of Task-Specific Human Capital needed for every occupation. For every occupation, a description is given and a list of competencies ascribed, necessary for efficiently carrying out the obligations attendant to the job. Also, a list is given of optional skills and competencies. The data bases vary somewhat in their descriptions of these processes.

These categorizations help to identify "task-specific" human capital. In ESCO, there are 13485 skills/competencies which are divided in: A (attitudes and Values), K (knowledge), L (language skills and knowledge) and S (skills). In O*NET, we encounter more categories, out of which we retain the following: Tasks, Knowledge, Skills, Abilities, Working Activities and Detailed Working Activities. There is, then, a common distinction in these two bases concerning occupational features between Knowledge and Skills while in $0^{*}$ NET there are also Abilities.

This distinction between occupations based on features is particularly important for understanding the requirements of human capital and can be helpful in better managing existing policies. Indeed, the distinction of human capital into knowledge, skills and competencies is not an innovation on the part of $0^{*}$ NET but widely referenced in the bibliography (Buta, 2015).

Initially, we need to distinguish between competencies on the one hand, and on the other, knowledge and skills. The latter are features which are acquired or intentionally cultivated by the workers, whereas competencies are categorizations to do with the employee and to the qualities of his characteristics. As far as knowledge and skills are concerned, they differ in what they describe and which their basic sources are they derive from. Knowledge refers to data and principles acquired in some field of information. 
To better understand the analysis of human capital into knowledge, skills, abilities and working activities, we include in the appendix an example of the human capital accrued in an occupation that wouldn't be thought to possess such characteristics, that of Logging Equipment Operator. It can thus be seen that the analysis of the characteristics of human capital is quite useful and illuminating regarding the way in which the labor market is organized.

It is seen that the basic source of knowledge accumulation is education, whereby one can accrue different types of information and understand a range of objects and their uses. Skills represent the processes of utilization and application of knowledge about the work process and they are acquired by the employee on the basis of experience. The requirements in skills, abilities and knowledge are formed on the basis of the tasks of every employee and the industry in which they work. Tasks comprise the Working Activities which the employee is called to perform, out of which stem all these requirements of human capital. On the basis of these four categories of employment characteristics (Knowledge, Skills, Abilities and Working Activities) the human capital which is required by every occupation can be described.

\section{Consequences of $4^{\text {th }}$ Industrial Revolution in the Structure of Human Capital: The Greek Case}

In the course of the $21^{\text {st }}$ century, labor markets are developing faster than ever, and especially with the onset of the $4^{\text {th }}$ industrial revolution, labor requirements are expected to change radically. To this, the COVID-19 crisis is added as an exogenous productive shock. Long-term forces (such as the $4^{\text {th }}$ industrial revolution) and shortterm ones (mainly COVID) interact and operate jointly.

For Greece, the effects of technological change do not result from COVID-19 but were already visible in the previous decade, during the fiscal crisis of 2010. If we isolate the effects of technological change on labor market tendencies (mainly through automation) during the previous crisis, we are able to see which industries were most impacted by it. In terms of intensity of impact, there are industries impacted worldwide according to the production structure of each country. For instance, according to the World Economic Forum (2020) the occupations in the USA with the greater pressure towards a technological shift were Computer Operators, Executive Secretaries and Executive Administrative Assistants, OI Word Processors and Typists and Telecommunications (Switchboard Operators including Answering Services and Telemarketing.)

Technological change has been occurring steadily in the past decade and the COVID19 crisis greatly reinforces it, with the result that the changes observable today in the labor market in terms of roles and occupations have a decidedly technological character. COVID-19 is an exogenous shock that affected the channels of distribution and demand through a sudden stop, and led to an acceleration in the shift of certain aspects of the production model. 
Occupations in which a decline in demand is observed internationally (World Economic Forum, 2020) relate to services of secretarial support and information provision, accountants, unspecialized labor (work in the production line of factories) but also specialized work (mechanics and machinery repairers).

On the other hand, under the impact of COVID-19, a range of technologies were accelerated. These technologies by order of importance in the process of acceleration are the following: Encryption and Cybersecurity, Cloud computing, Robots and NonHumanoid (e.g. industrial automation, drones), Augmented and Virtual Reality (1\%), Distributed ledger technology (e.g. blockchain), 3D Printing and Modeling, Artificial Intelligence etc. (BMI Research, 2018).

The coming decade will be defined by changes in labor distribution between human capital and material capital (machines). This shift (World Economic Forum 2020) will be more intense in branches where technology is already intensely present. Thus, new requirements are created for the structural elements and skills of human capital.

Regarding the Greek economy, the corresponding changes are presented in Diagram 1. Here, we see that the specializations with the greatest negative changes are waiters and related professions, cleaners and household helpers, customer information officers, cashiers, tellers and related professions, technical processing of food and clothing items. It is observed that these are products and services of low added value in relation to the GDP, although they do, nevertheless, have a pronounced presence in the productive structure. 
Diagram 1. Occupations with a decline in employment in Greece 2019-2020

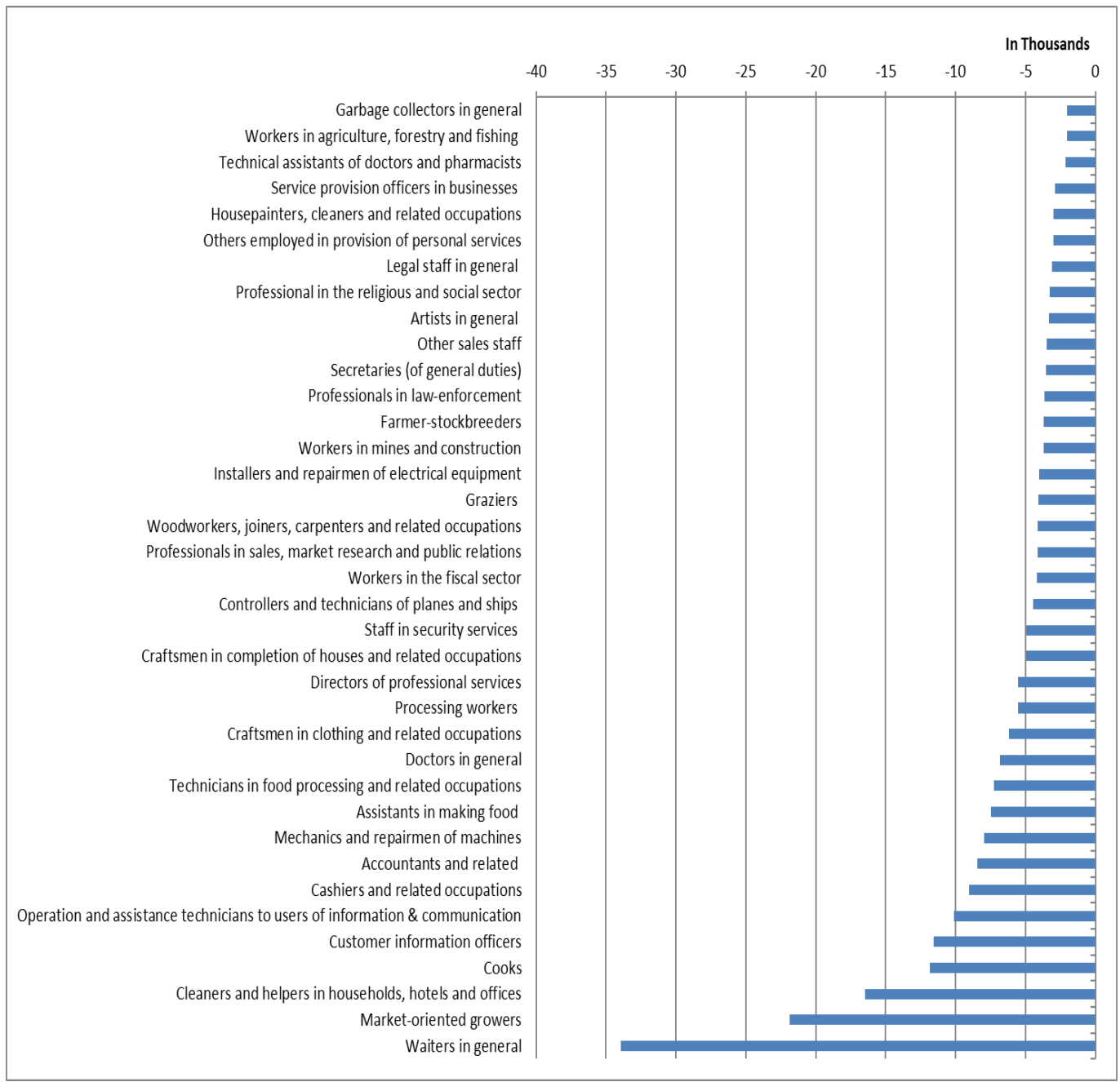

In diagram 2, we present the increases in occupations, mainly observed in administrative professionals, technical personnel in physics and engineering, mechanics (barring electricians), sales assistants in shops, hairdressers etc. 
Diagram 2: Occupations with an increase in employment in Greece 2019-2020

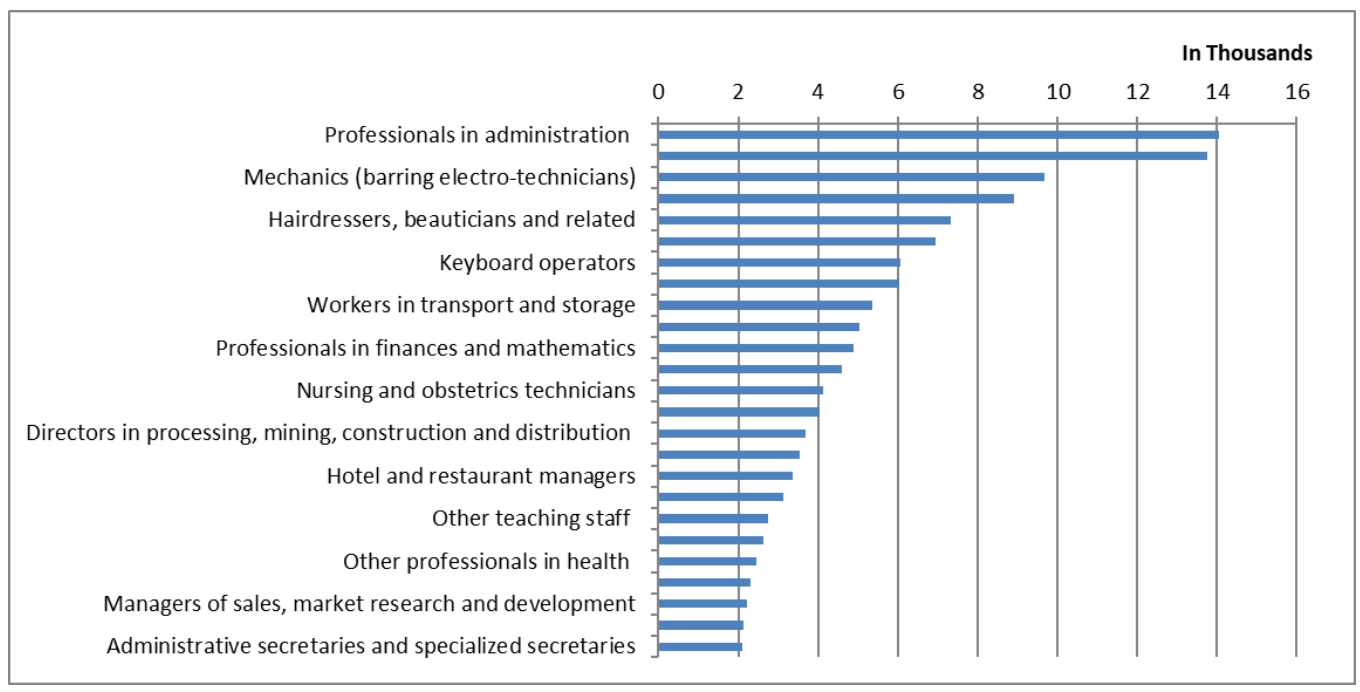

Changes in the distribution of labor are not expected to be the only ones in the production structure due to the $4^{\text {th }}$ industrial revolution. Alongside the above changes, actual occupational activities in the course of work are expected to change, not just the ratio of workers. This makes sense as technological developments are modifying production and, hence, the work environment.

Moreover, in Greece (OECD, 2018) there is a lack in skills to do with verbal, reasoning and perceptual abilities. Another aspect of the profile of Greek work skills has to do with digital literacy. In Greece (OECD, 2018; DESI 2018) digital skills are at low levels. The prevalent skills in Greek society (OECD, 2018) are concentrated in the positive sciences such as biology, but also in sectors such as architecture and engineering (mechanical and building/construction knowledge, and repairing and installation skills). In terms of levels of knowledge (OECD, 2018) Greek society rates quite a bit higher than the average country, although this is not reflected in the income levels of the workers.

The direction of upskilling and reskilling is towards the development of digital skills and the utilization of Communications and Information Technologies (CIT) as these expand in terms of microeconomics in the changing behaviors of the employed and, also, in terms of macroeconomics in digital enterprises, in the boosting of new entrepreneurship and investment opportunities and the simplification of certain procedures (Bank of Greece, 2018).

\section{Concluding Remarks}

In the next decade, a considerable portion of new employment positions will come into play in new occupational activities or in existing ones that will be substantially modified in terms of content, skills and abilities (Acemoglu \& Restrepo, 2018; Bessen, 
2019). The way human capital and employment posts will be affected is related to two issues: a) which sectors of the economy will register skill shortages and b) the extent to which qualifications are aligned with job requirements. The labor market is influenced by simultaneous forces in the one hand, and in the other by the financial crisis, the COVID-19 crisis and the $4^{\text {th }}$ Industrial Revolution.

COVID-19 reinforced the need for shifting the productive model in line with technological change. The observable changes in the labor market are a result of shifts in labor demands and, inductively, changes in the needs of enterprises. Understanding this process can explain the intensity of the demand for input of human capital in the service of producing the corresponding goods (material or immaterial) required by the economy. In these conditions, it is the quality of human capital that will define the comparative advantage of different countries, ceteris paribus, as well as the institutional framework, both at the level of productive infrastructure and in terms of the receptivity of different societies to (technological) change and entrepreneurship.

In Greece, professional, scientific and technical occupations are in shortage while the construction sector, by contrast, experiences a large occupational surplus (OECD 2018). Also, the forestry and fishing sector are facing occupational shortages. Essentially, the middle level of the production structure creates the preconditions for a demand side weakness while there is a surplus work force (a supply side weakness) who do not appear to be in a position to adapt to the requirements of the middle productive model, nor to create the supply conditions of a workforce that would mobilize a restructuring of production along contemporary requirements. Besides, brain drain absorbs critical quantities and qualities of human capital (Petrakis, 2020a) and, hence, operates as an additional factor stalling the development of an endogenous growth model centered on human capital.

With reference to the educational and lifelong learning systems the present and the future of the production model worldwide and especially in Greece, will be better served by the development of more flexible (low constant costs) educational structures for lifelong learning because, due to their nature they can adapt faster and efficiently to the rapid and major changes in the labor market. This approach is reasonable for two reasons. Firstly, conventional education is a solid institution that needs time to adjust to changes of the cultural background while lifelong learning educational structures adjust accordingly to changes in the labor market almost immediately. Secondly, in Greece, public spending for education is low (Heinrich \& Hildebrand, 2005) and unable to afford the upskilling and reskilling of the labor force.

Based on the features of technological change as well as the complexity of the occupational structure, we may conclude that the top upcoming skills for 2025 will have to do with analytic thinking and innovation, the solving of composite problems, creativity and the use of technology (Cedefop, 2018), lifelong learning, as well as psychological features such as resilience and stress management. To be sure, these 
changes concern entire vocational clusters and extend in every direction of the production structure.

The outcome will be new occupations shaped by: new technologies and demand, new products and services which create professional clusters and relate to green economy, to care economy, AI economy, new roles for engineering, cloud computing, marketing, sales and content productions. More specifically, the systematic use of technologies is included, such as two-sided digital platforms, mobile economy, the Internet and social media, intelligent machines and $\mathrm{AI}$, the economy of apps and of new technological trends such as interfacing, internet of things, big data 5G, encrypted coins and intangible assets and so on (Bank of Greece, 2018).

The specialization of the workforce leads to increased efficiency and production but has a social cost. Initially, the unspecialized labor force is displaced (specialization is required), the specialized unemployed may be discouraged because of the drastic changes and the costs involved in lifelong learning and turned into long-term unemployed, burdening the special security system. Also, specialization is a burdensome process which constrains creativity and, hence, the growth of entrepreneurship.

Concluding, technological change appears to point in the direction of technological specialization, which leads to an increase in the demand of specialized labor (Acemoglu \& Restrepo, 2018). This demand is associated with specific skills but not without cost. In fact, COVID-19 crisis led to intensification of technology and to the crowding out of jobs with a background in smaller routines (Chernoff \&Vartman, 2020; Acemoglu et al., 2021). A special issue to note regarding this direction, is that without adopting an interdisciplinary view, the persuasion of specialization will undermine creativity. That been, this must be resolved from the policy makers when they design the educational and lifelong learning systems as developing composite cognitive skills and abilities is a positive contribution to creative thinking.

\section{Acknowledgments}

The authors would like to thank A. Efstratoglou (PHD, INE/GSEE) for his contribution to the analysis of variables in the economy in the COVID-19 crisis. Also, the present paper is part of a wider research undertaking that is realized at the National Kapodistrian University of Athens under professor Panagiotis E. Petrakis.

\section{Appendix 1.}

Appendix 1 uses as a vocational example the Logging Equipment Operator from the $\mathrm{O}^{*} \mathrm{NET}$ data base, in terms of knowledge, skills, abilities and working activities. Below are presented the competencies involved in this particular occupation. The abilities relate to characteristics that serve in carrying out the requirements of the job, such as control of body posture, steadiness of hand movements etc. These abilities relate to inherent traits. 


\begin{tabular}{|l|l|}
\hline $\begin{array}{l}\text { Table 1: Basic Abilities Requirements (5 of 22) for 45-4022.00 - Logging Equipment } \\
\text { Operators }\end{array}$ \\
\hline Control Precision: & $\begin{array}{l}\text { The ability to quickly and repeatedly adjust the controls of a } \\
\text { machine or a vehicle to exact positions. }\end{array}$ \\
\hline Reaction Time: & $\begin{array}{l}\text { The ability to quickly respond (with the hand, finger, or foot) to a } \\
\text { signal (sound, light, picture) when it appears. }\end{array}$ \\
\hline $\begin{array}{l}\text { Arm-Hand } \\
\text { Steadiness: }\end{array}$ & $\begin{array}{l}\text { The ability to keep your hand and arm steady while moving your } \\
\text { arm or while holding your arm and hand in one position. }\end{array}$ \\
\hline $\begin{array}{l}\text { Multilimb } \\
\text { Coordination: }\end{array}$ & $\begin{array}{l}\text { The ability to coordinate two or more limbs (for example, two } \\
\text { arms, two legs, or one leg and one arm) while sitting, standing, or } \\
\text { lying down. It does not involve performing the activities while the } \\
\text { whole body is in motion. }\end{array}$ \\
\hline Depth Perception: & $\begin{array}{l}\text { The ability to judge which of several objects is closer or farther } \\
\text { away from you, or to judge the distance between you and an } \\
\text { object. }\end{array}$ \\
\hline Source: https://www.onetonline.org/link/summary/45-4022.00 \\
\hline
\end{tabular}

Table 2 presents the knowledge required in the occupation of Logging Equipment Operator which derive as a result of education system. This type of knowledge may correspond to other occupations with same requirements, though, the intensity in the use of such knowledge is the differentiating factor among occupations requirements (Handel, 2016).

Table 2: Knowledge Requirements for 45-4022.00 - Logging Equipment Operators

Mechanical:

Knowledge of machines and tools, including their designs, uses, repair, and maintenance. Knowledge of relevant equipment, policies, procedures, and strategies to promote

Public Safety and Security: effective local, state, or national security operations for the protection of people, data, property, and institutions.

Knowledge of raw materials, production

Production and Processing: processes, quality control, costs, and other techniques for maximizing the effective manufacture and distribution of goods.

Source: https://www.onetonline.org/link/summary/45-4022.00 
Table 3 presents the skills requirements for the Logging Equipment Operator which are a result of learning by doing.

\begin{tabular}{|l|l|}
\hline \multicolumn{2}{|c|}{ Table 3: Skills Requirements for 45-4022.00 - Logging Equipment Operators } \\
\hline Operation and Control: & $\begin{array}{l}\text { Controlling operations of equipment or } \\
\text { systems. }\end{array}$ \\
\hline Operation Monitoring: & $\begin{array}{l}\text { Watching gauges, dials, or other indicators to } \\
\text { make sure a machine is working properly. }\end{array}$ \\
\hline Equipment Maintenance: & $\begin{array}{l}\text { Performing routine maintenance on } \\
\text { equipment and determining when and what } \\
\text { kind of maintenance is needed. }\end{array}$ \\
\hline Active Listening: & $\begin{array}{l}\text { Giving full attention to what other people are } \\
\text { saying, taking time to understand the points } \\
\text { being made, asking questions as appropriate, } \\
\text { and not interrupting } \\
\text { at inappropriate times. }\end{array}$ \\
\hline Monitoring: & $\begin{array}{l}\text { Monitoring/Assessing performance of } \\
\text { yourself, other individuals, or organizations to } \\
\text { make improvements or take corrective action. }\end{array}$ \\
\hline Quality Control Analysis & $\begin{array}{l}\text { Conducting tests and inspections of products, } \\
\text { services, or processes to evaluate quality or } \\
\text { performance. }\end{array}$ \\
\hline Troubleshooting & $\begin{array}{l}\text { Determining causes of operating errors and } \\
\text { deciding what to do about it. }\end{array}$ \\
\hline Source: https://www.onetonline.org/link/summary/45-4022.00 \\
\hline
\end{tabular}

All of the above were ascribed to the occupation of the Logging Equipment Operator on the basis of the tasks that need to be carried out and which in essence, comprise the working activities (table 4)

Table 4: Working Activities (5/27) for 45-4022.00 - Logging Equipment Operators \begin{tabular}{|l|l|}
\hline Operating Vehicles, Mechanized & Running, maneuvering, navigating, or driving
\end{tabular} Devices, or Equipment vehicles or mechanized equipment, such as forklifts, passenger vehicles, aircraft, or water craft.

Using either control mechanisms or direct

Controlling Machines and Processes physical activity to operate machines or processes (not including computers or vehicles).

Repairing and Maintaining Servicing, repairing, adjusting, and testing Mechanical Equipment machines, devices, moving parts, and equipment that operate primarily on the basis of mechanical (not electronic) 


\begin{tabular}{|l|l|}
\hline & principles. \\
\hline Getting Information & $\begin{array}{l}\text { Observing, receiving, and otherwise obtaining } \\
\text { information from all relevant sources. }\end{array}$ \\
\hline Monitoring: & $\begin{array}{l}\text { Monitoring/Assessing performance of } \\
\text { yourself, } \\
\text { other individuals, or organizations to make } \\
\text { improvements or take corrective action. }\end{array}$ \\
\hline $\begin{array}{l}\text { Inspecting Equipment, Structures, or } \\
\text { Material }\end{array}$ & $\begin{array}{l}\text { Inspecting equipment, structures, or materials } \\
\text { to identify the cause of errors or other } \\
\text { problems or defects. }\end{array}$ \\
\hline Source: https://www.onetonline.org/link/summary/45-4022.00 \\
\hline
\end{tabular}

\section{References}

[1] Acemoglu, D., \& Autor, D. (2011). Skills, tasks and technologies: implications for employment and earnings. In O. Ashenfelter \& D. Card (Eds.), Handbook of Labor Economics (1st edition ed., Vol. 4b, pp. 1044-1172). North Holland. https://www.amazon.com/Handbook-Labor-EconomicsOrleyAshenfelter/dp/0444534520

[2] Acemoglu, D., Autor, D., Hazell, J. \& Restrepo, P. (2020). AI and Jobs: Evidence from Online Vacancies. National Bureau of Economic Research. 10.3386/w28257 https://www.nber.org/papers/w28257

[3] Acemoglu, D \& Restrepo, P. (2018). Artificial Intelligence, Automation and Work. National Bureau Of Economic Research. 10.3386/w24196 https://www.nber.org/papers/w24196

[4] Autor, D. H. (2013). The "Task Approach" to Labor Markets: An Overview. National Bureau of Economic Research Working Paper Series, 18711. https://doi.org/10.3386/w18711

[5] Arrow, K., Dasgupta, P., Goulder, L., Daily, G., Ehrlich, P., Heal, G., Levin, S., Mäler, K.-G., Schneider, S., Starrett, D., \& Walker, B. (2004). Are We Consuming Too Much? Journal of Economic Perspectives, 18(3), 147-172. https://doi.org/10.1257/0895330042162377

[6] Bank of Greece. (2018). Governor's Annual Report. Bank of Greece Printing Works. https://www.bankofgreece.gr/en/publications-andresearch/publications/governors-annual- report

[7] BMI Research. (2018). Towards 2050: Megatrends In Industry, Politics And The Global Economy,2018 Edition. BMI15658437

[8] Becker, G. S. (1994). Human Capital: A Theoretical and Empirical Analysis, with Special Reference to Education, 3rd Edition (3rd edition). University of Chicago Press. 
[9] Bernard, P., Owen, R., \& Maclure, W. (1988). Irreconcilable Opinions: The Social and Educational Theories of Robert Owen and William Maclure. Journal of the Early Republic, 8(1), 21-44. doi:10.2307/3123663

[10] Bessen, J .(2019). Automation and jobs: when technology boosts employment, Economic Policy. 34(100), 589-626. https://doi.org/10.1093/epolic/eiaa001

[11] Bloom, D. E., Canning, D., Chan, K., \& Luca, D. L. (2014). Higher Education and Economic Growth in Africa. International Journal of African Higher Education, 1(1). https://doi.org/10.6017/ijahe.v1i1.5643

[12] Borjas, G. (2015). Labor Economics (7th edition). McGraw-Hill Education.

[13] Buta, S. (2015). Human capital theory and human resource management. Implications in develeopment of knowledge management strategies. EcoForum, 4(1(6)), 155-162.

[14] Cedefop - European Centre for the Development of Vocational Training (2018) Cedefop's European skills index: new tool for informed policy-making. doi:10.2801/7667

[15] Chernoff, A.W.\& Warman, C. (2020). Covid-19 and Implications for Automation. National Bureau of Economic Research. https://www.nber.org/papers/w27249. 10.3386/w27249

[16] Collier, P. (2017). African urbanization: An analytic policy guide. Oxford Review of Economic Policy, 33(3), 405-437. https://doi.org/10.1093/oxrep/grx031

[17] DESI - The Digital Economy and Society Index. (2018). Country Report for Greece.

https://ec.europa.eu/information_society/newsroom/image/document/20 18-20/el-desi_2018- country-profile-lang_4AA59C97-CC3B-7C259CE4F07248577AD8_52343.pdf?fbclid=IwAR28DvPfcC2lL_me8028JEDEQq ZzJgaiah4Uj bQ8IejfthOPG8KjcrpNJrQ

[18] Dimand, R., \& Spencer, B. (2008). Trevor Swan And The Neoclassical Growth Model (No. w13950; p. w13950). National Bureau of Economic Research. https://doi.org/10.3386/w13950

[19] Dui, H.-J. (2020). Human Capital and Economic Growth: A Systematic Review. International Journal of Economics and Management Studies, 7(11), 1-7. https://doi.org/10.14445/23939125/IJEMS-V7I11P101

[20] Galor, O., \& Weil, D. N. (2000). Population, Technology, and Growth: From Malthusian Stagnation to the Demographic Transition and beyond. The American Economic Review, 90(4), 806-828. Gibbons, R., \& Waldman, M. (2004). Task-Specific Human Capital. The American Economic Review, 94(2), 203-207.

[21] Glewwe, P., Maïga, E., \& Zheng, H. (2014). The Contribution of Education to Economic Growth: A Review of the Evidence, with Special Attention and an Application to Sub-Saharan Africa. World Development, 59, 379-393. https://doi.org/10.1016/j.worlddev.2014.01.021 
[22] Goldin, C. (2016). Human Capital. In C. Diebolt \& M. Haupert (Eds.), Handbook of Cliometrics (pp.55-86). Springer-Verlag. https://www.springer.com/gp/book/9783642404078

[23] González-Salamanca, J. C., Agudelo, O. L., \& Salinas, J. (2020). Key Competences, Education for Sustainable Development and Strategies for the Development of 21st Century Skills. A Systematic Literature Review. Sustainability, 12(24) 10366. https://doi.org/10.3390/su122410366

[24] Handel, M. (2016). The O*NET content model: Strengths and limitations. Journal for Labour Market Research, 49. https://doi.org/10.1007/s12651016-0199-8

[25] Heinrich, G. and Hildebrand, V. (2005), Returns to Education in the European Union: a re-assessment from comparative data. European Journal of Education, 40: 13-34. https://doi.org/10.1111/j.1465-3435.2005.00207.x

[26] Lucas, R. E. (1988). On the mechanics of economic development. Journal of Monetary Economics, 22(1), 3-42. https://doi.org/10.1016/03043932(88)90168-7

[27] Mankiw, N. G., Romer, D., \& Weil, D. N. (1992). A Contribution to the Empirics of Economic Growth. The Quarterly Journal of Economics, 107(2), 407-437. https://doi.org/10.2307/2118477

[28] Maremveliotakis, G., \& Manioudis, M. (Forthcomming). History, Knowledge and Sustainable Economic Development: The Contribution of Mill's Grand Stage Theory. Sustainability, 13.

[29] Mincer, J. (1958). Investment in Human Capital and Personal Income Distribution'. Journal of Political Economy, 66(4), 281-302.

[30] Neal, D. (1995). Industry-Specific Human Capital: Evidence from Displaced Workers. Journal of Labor Economics, 13(4), 653-677.

[31] Nelson, R., \& Phelps, E. (1966). Investment in Humans, Technological Diffusion, and Economic Growth. American Economic Review, 61, 69-75.

[32] Ngai, L. R., \& Petrongolo, B. (2017). Gender Gaps and the Rise of the Service Economy. American Economic Journal: Macroeconomics, 9(4), 1-44. https://doi.org/10.1257/mac.20150253

[33] OECD-Organisation for Economic Co-operation and Development. (2001). Annual Report 2001. https://www.oecd-ilibrary.org/economics/oecdannual-report-2001_annrep-2001-en

[34] OECD-Organisation for Economic Co-operation and Development. (2018). Skills For Jobs - Greece. OECDPublishing. https://www.oecdskillsforjobsdatabase.org/data/country_notes/Greece\% 20 country\%20note.pdf?fbclid=IwAR0RVv1jAXgl2NNHbIDHRKLUyatphyPrFxd bfPmbi56ELivnPs9M- 2NKSnw

[35] Olamosu, B., \& Wynne, A. (n.d.). Africa rising? The economic history of subsaharan africa. International Socialism, 146(00), 01. 
[36] Osiobe, E. (2019). A Literature Review of Human Capital and Economic Growth. Business and Economic Research, 9(4), 179-196.

[37] Petrakis, P. E. (2020a). The new political economy of Greece up to 2030. Palgrave Macmillan.

[38] Petrakis, P. E. (2020b). Theoretical approaches to economic growth and development: An interdisciplinary perspective. Palgrave Macmillan.

[39] Romer, P. (1990). Endogenous Technological Change. Journal of Political Economics, 98(5), 71-102.

[40] Sarquis, J. B., \& Arbache, J. S. (2002). Human Capital, External Effect and Technical Change. London School of Economics.

[41] Schultz, T. W. (1961). Investment in Human Capital. American Economic Review, 51, 1-17.

[42] Shaw, K. L. (1984). A Formulation of the Earnings Function Using the Concept of Occupational Investment. The Journal of Human Resources, 19(3), 319-340. https://doi.org/10.2307/145876

[43] Smith, A. (2007). An Inquiry into the Nature and Causes of the Wealth of Nations (S. M. Soares, Ed.). MetaLibri Digital Library.

[44] Solow, R. M. (1956). Contribution to the Theory of Economic Growth. The Quarterly Journal of Economics, 70(1).

[45] Spengler, J. J. (1977). Adam Smith on Human Capital. The American Economic Review, 67(1), 32- 36.

[46] Winthrop, R., McGivney, E., \& Barton, A. (2018). Leapfrogging Inequality: Remaking Education to Help Young People Thrive. Brookings Institution Press. https://www.brookings.edu/ book/leapfrogging-inequality-2/

[47] World Bank. (2019). Building Human Capital. In World Development Report 2019: The Changing Nature of Work. World Bank.

[48] World Economic Forum. (2020). The Future of Jobs Report 2020. https://www.weforum.org/reports/the-future-of-jobs-report-2020 